Bull. Fac. Agric., Cairo Univ., 66:307-319 (2015).

\title{
INFLUENCE OF DIFFERENT REPLACEMENT LEVELS OF SPROUTED WHEAT AND BARLEY GRAIN FLOUR ON CAKE QUALITY
}

(Received:26.10.2015)

\author{
By \\ M. H. A.El- kader, N. S.Yousef*, S. M. El-Sayed* and G. A. H. Asker* \\ Bread and Pastries Research Departmeny, Food Technology Research Institute, Agriculture Research \\ Center, Giza, Egypt *Food Science and Technology Department, Home Economic, \\ Al- Azhar University, Tanta, Egypt
}

\begin{abstract}
The present investigation was designed to study the influence of replacement of wheat flour by either sprouted wheat or barley flour at different levels, i.e. 5, 10 and $15 \%$ on the produced cake quality. The minerals content showed an increase due to sprouting wheat or barley flour compared with unsprouting one. The increase of bioavailability of minerals may be due to sprouting which decreased phytic acid content by about 32.36 and $35.99 \%$, for wheat and barley, respectively. Phytate/phosphorus percentages were reduced and reached 61.55 and $35.20 \%$ in sprouted wheat and barley flour, respectively. Phytate/Fe and phytate/Ca molar ratios decreased in sprouted wheat and barley compared with unsprouted one, whereas Phytate/Zn molar increased in sprouted barley flour. The rheological tests showed an increase in water absorption, weakening degree with replacement by sprouted barley than sprouted wheat compared with the control, and a decrease in stability. The decrease of elasticity and extensibility was higher with sprouted barley flour than in sprouted wheat compared with the control. The results of falling No showed that, alfa amylase activity in both sprouted wheat and barley was higher than unsprouted. The cakes prepared with different replacement levels of sprouted wheat and sprouted barley $(5,10$, and15\%) had good acceptability in sensorial evaluation in all samples. Cake prepared with different levels of sprouted barley flour were more brilliant than cake prepared with sprouted wheat for physical properties compared with control. Texture profile analysis for the cake showed decrease in hardness, chewiness, cohesiveness and resilience in sprouted wheat cake than the control. Water activity for cake decreased with increasing sprouted barley replacement levels. Cake prepared with different replacement of sprouted wheat was excellent in graining, texture, crumb color, taste and odor than that prepared with sprouted barley flour.
\end{abstract}

Key words: sprouted wheat, sprouted barley, phytic acid, mineral content, mineral availability, rheological properties, cake.

\section{INTRODUCTION}

The consumers' awareness of the need to eat high quality and healthy foods known as functional foods, that is, foods which contain ingredients that provide additional health benefits beyond the basic nutritional requirements, has increased (Nadife and Abbo, 2009). The consumption of functional foods not only improves the nutritional status of the general population, but also helps those suffering from degenerative diseases associated with changing life styles and environment. Sprouted grains are seen in a number of baked goods at natural health food stores. The concept behind the use of such grains and legumes is that the enzymes produced during sprouting convert starch into more digestible maltose and the vitamins and mineral content available for digestion increases (Dhingra and Jood, 2001). Germination induces increase in free limiting amino acid and available vitamins with modified functional properties of seed components (Hallén and Ainsworth. 2004). 
Germination also decreases anti-nutritional factors such as trypsin-inhibitor (Uwaegbute et al., 2000).

Scientific studies have reported that wheat contains appreciable amounts of nutrient and antinutritional factors (Muahamed et al., 2010). Barley contains large quantities of phytate, which are the major storage form of phosphorus in plants. Phytate negatively affects the bioavailability of essential minerals by forming insoluble mineralphytate complexes at physiological $\mathrm{pH}$ and thereby inhibiting absorption. In humans, phytic acid is a chelating agent, which binds nutritionally important mono- and divalent minerals i.e., $\mathrm{Ca}$, $\mathrm{Mg}, \mathrm{Mn}, \mathrm{Zn}$ and $\mathrm{Fe}$ (Bhavsar et al., 2008). An increase in bioavailability of minerals and weight has been observed during seed germination. Germinated seeds are good source of ascorbic acid, riboflavin, choline, thiamine, tocopheroles and pantothenic acid (Sangronis and Machado, 2007).

The aim of the present study was to investigate the effect of sprouted wheat and barley grains on the quality of the produced cakes.

\section{MATERIALS AND METHODS \\ 2.1. Materials}

Wheat grains (Triticum aestivum) Gemmeiza 11 and barley grains (Hordeum vulgare L) Giza 132 were obtained from Crops Research Institute, Agriculture Research Center, Giza, Egypt. Skimmed milk powder, sugar, butter, baking powder, vanillin, and fresh hen eggs were purchased from the local market.

\subsection{Methods}

\subsubsection{Preparation of wheat and barley flour}

The grain samples were soaked in distilled water $(1: 5 \mathrm{w} / \mathrm{v})$ for $12 \mathrm{hr}$ at room temperature $\left(25 \pm 5^{\circ} \mathrm{C}\right)$ to get a moisture content of about 38$40 \%$. Excess water was drained off. The presoaked wheat was allowed sprouting for 24hr, while barley grains were left for $48 \mathrm{hr}$. at room temperature $\left(25 \pm 2^{\circ} \mathrm{C}\right)$ even sprout appeared. The samples were washed by tap water to avoid yeast and fungus infection. Sprouted wheat and barley grains were dried in an oven air dryer at $55^{\circ} \mathrm{C}$ to about 12\% moisture content (Youssef, 2008). Unsprouted wheat and barley grains were cleaned and washed by tap water, then sun dried for $24 \mathrm{hr}$ during July. Dried sprouted and unsprouted wheat and barley grains were ground using Quadrumat junior mill (Brabender, Germany) to obtain whole meal flour (Hussein et al., 2013).

\subsubsection{Determination of minerals content}

The standard method for mineral content analysis was used as described by (A.O.A.C., 2005). Phosphorus was determined calorimetrically using inductively coupled plazma (ICP) Spectrometry (ultimazjy) plazma with $\mathrm{KH}_{2} \mathrm{PO}_{4}$ as standard. While, $\mathrm{Na}$ and $\mathrm{K}$ were determined using the standard flame emission photometer. Atomic Absorption spectrophotometer [AAS Model SP9] was used to determine Mn, Zn, $\mathrm{Ca}, \mathrm{Mg}$ and $\mathrm{Fe}$. All values were expressed in $\mathrm{mg}$ $/ 100 \mathrm{~g}$.

\subsubsection{Determination of phytic acid content}

Phytate extraction was conducted according to the procedure described by Harland and Oberleas (1977), meanwhile the procedure of Mohamed et al. (1986) was used for determination. The amount of phytate in the tested samples was expressed as mg phytate/100g sample on dry weight basis.

\subsubsection{Phytate phosphorus determination}

Phytate phosphorus (mg/ 100g) is equal to [phytic acid content in $\mathrm{mg} / 100 \mathrm{gm} \times 0.2818$ ] as mentioned by Tizazu et al.(2011).

\subsubsection{Phytate - Mineral molar ratios determination}

Molar ratio between phytate/mineral was used to determine the bioavailability of minerals. The mole of phytate and minerals were obtained by dividing the mass of phytate and minerals by its atomic mass respectively (phytate: $660 \mathrm{~g} / \mathrm{mol}$; Fe: $56 \mathrm{~g} / \mathrm{mol}$; Zn: $65 \mathrm{~g} / \mathrm{mol}$; Ca: $40 \mathrm{~g} / \mathrm{mol}$ ). The molar ratio between phytate and mineral was determined by dividing the mole of phytate to the mole of mineral. (Shimi and Hasnah 2013).

\subsubsection{Rheological tests}

Farinograph and Extensograph parameters were measured according to the methods described in the A.A.C.C. (2010). Falling number was determined according to the method described in A.A.C.C. (2000) and liquefaction number was calculated according to Finney (2001) as follow:

\section{Whereas:}

Liquefaction No. $=6000 /$ Falling No. -50 .

\section{$6000=$ constant number}

$50=$ the number correspond approximately to the time in seconds required for the flour starch to gelatinized sufficiently so that it will be attack by the enzyme. 


\subsubsection{Cake formula and preparation}

The cake formula constituted $100 \mathrm{~g}$ of wheat flour, $85 \mathrm{~g}$ of sucrose, $55 \mathrm{~g}$ of shortening, $3 \mathrm{~g}$ of dried skimmed milk, $85 \mathrm{~g}$ of fresh whole egg, $3.8 \mathrm{~g}$ of baking powder and $0.6 \mathrm{~g}$ of vanillin (as control). Sprouted wheat and sprouted barley flour were separately replaced wheat flour at levels of 5, 10 and $15 \%$. The cake prepared by creamed fat for 3 min then sugar was added and beaten for $2 \mathrm{~min}$. Egg and vanillin were beaten well for $5 \mathrm{~min}$ then added to the creamed mixture. The flour and baking powder mixture were added gradually to previous mixture and genteelly mixed for $5 \mathrm{~min}$. Cake dough was placed on pan cake, and baked at $180^{\circ} \mathrm{C}$ for $30 \mathrm{~min}$ in a preheat oven. The cake samples were left to cool at room temperature, then packed in low density polyethylene bags, (Bennion and Bamford, 1973).

\subsubsection{Sensory evaluations of pan cake}

Sensory evaluation of cake samples was performed by ten members in the Bread and Pasty Research Department, Food Tech. Res. Instit. Agric. Res. Center. The quality of fresh pan cake was evaluated according to the method described in A.A.C.C. (2000). The used scores were 15 for volume, 10 for uniformity of shape, 5 for crust characteristic, 10 for graining of crumb, 5 for crumb color, 15 for texture, 30 for taste and 10 for odor.

\subsubsection{Physical characteristics of pan cake}

The internal characteristics (texture) of the cakes were evaluated according to Bourne, (2003) in term of TPA by Texture Profile Analyzer (Cometech, B type, Taiwan) provided with soft ware with double compression test to penetrate samples size $40 * 40 * 30 \mathrm{~mm}$ to $50 \%$ depth, at 1 $\mathrm{mm} / \mathrm{s}$ speed test. Water activity in cake samples was measured with a Rotronic (model Hygrolab3 made in Switzerland) according to the method described by Piga et al. (2005). Cake volume $\left(\mathrm{cm}^{3}\right)$ was determined according to A.A.C.C. (1983). While, specific volume of cake samples was calculated as follows:

Specific volume $=$ Cake volume $\left(\mathrm{cm}^{3}\right) /$ Cake weight (gm)

\subsubsection{Statistical analysis}

The results were statistically analyzed by analysis of variances according to SPSS (1997). Significant differences among individual means were analyzed by Duncan's multiple range tests (Duncan, 1995).

\section{RESULTS AND DISCUSSION 3.1. Minerals contents of wheat and barley flour samples}

The minerals content of wheat and barley flour and sprouted ones showed a noticeable improvement in all mineral contents in sprouting grain except zinc (Table 1).

Sprouted barley flour had higher content of minerals than sprouted wheat flour. The increase of minerals as a result of sprouting may be due to the consumption of the main component of the grain flour such as carbohydrate, protein and lipids during germination. The decrease in these components reflects the increasing of minerals besides its possibility to be free. Badi (2004) showed that improvement of minerals availability $\%(\mathrm{Ca}, \mathrm{P}, \mathrm{Mn}$ and $\mathrm{Co}$ ) referred to the germinated sorghum varieties and resulted in a reduction of both tannin and phytate.

\subsection{Phytate and phytate phosphorus content}

Table (2) showed that, the highest value of phytic acid was found in wheat flour whereas, the lowest value was found in sprouted barley flour. Soaking and germination process recording a loss in phytate levels by $32.46 \%$ and $35.99 \%$ in wheat and barley flour, respectively. The reduction in phytate caused by soaking may be due to the hydrolysis and the liberation of the minerals followed by the solubilization of phytic acid salts. Bhavsar et al. (2008) mentioned that phytic acid is a chelating agent, which binds nutritionally important mono- and divalent minerals (i. e., calcium, magnesium, cobalt, manganese, zinc, copper, and iron) to form a complex phytate. Konietzny and Greiner (2002) reported that during soaking and germination of cereal seeds phytate level decreases with increasing of the phytase activity. The phytases hydrolyse the phytic acid to myo-inositol and phosphoric acid in a stepwise manner, forming myo-inositol phosphate intermediates. Various studies implicated the reduction in phytate levels due to enzymatic changes during seed germination (Khattak et al., 2007). Phytate phosphorus was higher in both of wheat and barley flour (321.25 and 317.87 $\mathrm{mg} / 100 \mathrm{~g}$, respectively) and lower in sprouted wheat and barley flour (217.27 and 203.46 $\mathrm{mg} / 100 \mathrm{~g}$, respectively). As mentioned by Tizazu et al. (2011), after sprouting phytate phosphorus decreased as a result of phytate reduction. 
Table (1): Mineral contents (mg/100g) of wheat and barley flour samples (as dry weight basis).

\begin{tabular}{lcccc}
\hline \multirow{2}{*}{ Minerals } & \multicolumn{4}{c}{ Flour samples } \\
\cline { 2 - 5 } Mn & 1.84 & 2.23 & 2.19 & 2.56 \\
Na & 33.02 & 40.72 & 20.70 & 60.17 \\
K & 27.26 & 34.26 & 45.82 & 46.23 \\
Fe & 1.49 & 1.81 & 3.28 & 5.09 \\
ba flour & Bheat flour & Barley flour & \\
Zn & 116.21 & 150.59 & 235.64 & 240.16 \\
Mg & 4.75 & 3.72 & 5.67 & 3.36 \\
P & 75.60 & 100.69 & 143.57 & 152.17 \\
\hline
\end{tabular}

Table (2): Phytate and phytate phosphorus contents of wheat and barley flour samples (mg/100g).

\begin{tabular}{|c|c|c|c|c|c|}
\hline $\begin{array}{l}\text { Flour } \\
\text { Samples }\end{array}$ & $\begin{array}{l}\text { Phytate } \\
\text { content } \\
(\mathrm{mg} / 100 \mathrm{gm})\end{array}$ & $\begin{array}{c}\text { Phytate } \\
\text { loss, \% }\end{array}$ & $\begin{array}{c}\text { Total } \\
\text { phosphorus } \\
\text { (mg/100gm) }\end{array}$ & $\begin{array}{c}\text { Phytate } \\
\text { Phosphorus } \\
\text { (mg/100gm) }\end{array}$ & $\begin{array}{c}\text { *Phytate } \\
\text { Phosphorus, } \\
\%\end{array}$ \\
\hline Wheat flour & 1140 & -- & 350 & 321.25 & 91.79 \\
\hline $\begin{array}{l}\text { Sprouted } \\
\text { Wheat flour }\end{array}$ & 771 & 32.36 & 353 & 217.27 & 61.55 \\
\hline Barley flour & 1128 & -- & 319 & 317.87 & 99.65 \\
\hline $\begin{array}{l}\text { Sprouted } \\
\text { Barley flour }\end{array}$ & 722 & 35.99 & 578 & 203.46 & 35.20 \\
\hline
\end{tabular}


The percentages of phytate phosphorus in wheat and barley flour were 91.79 and $99.65 \%$, respectively. After sprouting, the phytate phosphorus was decreased in both wheat and barley flour to 61.55 and $35.20 \%$, respectively. The decrease of phytate phosphorus may be due to the enzymatic hydrolysis during germination (Khattak et al., 2007) and confirmed the results of Borode et al. (1984).

\subsection{Phytate-Mineral molar ratios}

The bioavailability of minerals in the human body could be determined by measuring the molar ratio of phyate/ minerals in the food and diet (Morris and Ellis, 1989). The proportion of samples with ratios above the suggested critical values has been calculated: phytate: calcium > 0.24 (Morris and Ellis, 1985), phytate: iron > 1 (Hallberg et al., 1989), phytate: zinc > 15 (Turnlund et al.,1984; Sandberg et al., 1987; Morris and Ellis, 1989), [phytate] [calcium] /[zinc] ratio> 200 (Davies et al.,1985; Bindra, et al., 1986).

Phytate/Fe, Phytate/Zn and Phytate/Ca molar ratios of wheat, sprouted wheat, barley and sprouted barley flour were associated with iron, zinc and calcium absorption capacity (Table 3 ).

It could be noticed that the phytate/Zn molar ratio in barley flour was lower (19.59) than sprouted (21.16), whereas, higher in wheat 23.63 than in sprouted ones (20.42).

Meanwhile, the phytate/Fe molar ratio was 12.03 and 29.16 for sprouted and unsprouted barley flour, respectively. Whereas, the phytate/Fe molar ratio was 36.16 and 64.92 for sprouted and unsprouted wheat flour, respectively.

The Phytate/Ca molar ratios ranged between 0.18 for sprouted barley flour and 0.31 for sprouted wheat flour.

The present results proved that phytate/Fe and phytate/Ca molar ratios decreased and this may be due to medium iron and calcium bioavailability of sprouted wheat and barley flour.

These data of sprouted barley flour confirm those reported by Kayodé (2006) who found that the Phytate /Fe molar was ratio lower than 14, which is the critical value and above 14 the availability of $\mathrm{Fe}$ is strongly impaired. Samples with Phytate/Zn molar ratios between 5 and 15 have medium zinc bioavailability and those with a Phytate/Zn molar ratio less than 5 have relatively good zinc bioavailability (Alemu, 2009).
Sprouting had thus proved beneficial in lowering the phytic acid content and improving the bioavailability of dietary essential minerals. Once the phytate content is reduced by this simple traditional process, wheat and barley would become a potential source of minerals.

\subsection{Farinograph assessment}

The water absorption, arrival time and dough development time increased with increasing the replacement levels of sprouted wheat flour and sprouted barley flour (Table 4).

This increment in water absorption may be due to either high fiber content or to the bio-synthesis component during sprouting process in whole sprouted wheat flour and sprouted barley flour compared to wheat flour. Miś, (2003) confirmed that the effects of enzymatic hydrolysis of gluten proteins with an increase in the sprouting degree initially appear in lifting the sorption abilities of gluten. Simultaneously the gluten stores more and more higher contents of the nonabsorbed water, and its mechanical strength weakens .These results argree with those obtained by (Eissa et al.,2007) who found that water absorption, dough development time and dough weakening increased but dough stability decreased in the case of raw and germinated legumes flours replaced with Wheat flour in ratios of 5, 10, and $15 \%$.

Dough stability decreased gradually from 4.5 to 3.5 min due to increasing of the level replacement of sprouted wheat, but, the decrease was rapidly from $3 \mathrm{~min}$ to $2.0 \mathrm{~min}$ with sprouted barley flour. At the same time the weakening were rapidly increased due to the replacement with sprouted barley flour compared with control, and were constant in sprouted wheat flour levels. This result may be due to gluten hydrolysis by the increased proteolitic activity during germination (Holas and Tipples, 1978).

\subsection{Extensogrph assessment}

The elasticity of samples replaced by sprouted wheat and barley flours decreased gradually with increasing the replacement levels, while the extensibility of the same samples increased. This might be due to proteolitic enzyme activity and gluten hydrolysis (Indrani and Rao, 2000). With respect to sprouted barley flour replacement the extensibility values were higher in comparison with sprouted wheat flour with increasing the replacement levels (Table 5). 
Table (3): Phytate minerals molar ratios of wheat and barley flour samples.

\begin{tabular}{lccc}
\hline Samples & $\begin{array}{l}\text { Phytate/Zn } \\
\text { (Molar ratio) }\end{array}$ & $\begin{array}{l}\text { Phytate /Fe } \\
\text { (Molar ratio) }\end{array}$ & $\begin{array}{c}\text { Phytate/Ca } \\
\text { (Molar ratio) }\end{array}$ \\
\hline Wheat flour & 23.63 & 64.92 & 0.59 \\
Sprouted wheat flour & 20.42 & 36.16 & 0.31 \\
Barley flour & 19.59 & 29.16 & 0.29 \\
Sprouted barley flour & 21.16 & 12.03 & 0.18 \\
\hline
\end{tabular}

Table (4): Farinograph parameters of sprouted wheat and barley flour blends.

\begin{tabular}{lccccc}
\hline Treatments & $\begin{array}{c}\text { Water } \\
\text { Absorption } \\
(\%)\end{array}$ & $\begin{array}{c}\text { Arrival } \\
\text { Time } \\
(\text { min })\end{array}$ & $\begin{array}{c}\text { Dough } \\
\text { Development } \\
(\text { min })\end{array}$ & $\begin{array}{c}\text { Stability } \\
(\text { min })\end{array}$ & $\begin{array}{c}\text { Weakening } \\
(\text { BU })\end{array}$ \\
\hline Wheat flour(control) & 73.7 & 1.0 & 2.0 & 4.5 & 110 \\
Sprouted wheat flour & & & & & \\
$5 \%$ & 74.1 & 1.0 & 2.0 & 4.5 & 130 \\
$10 \%$ & 74.6 & 1.0 & 2.5 & 4.0 & 130 \\
$15 \%$ & 74.9 & 1.5 & 3.0 & 3.5 & 130 \\
Sprouted barley flour & & & & & \\
$5 \%$ & 79.2 & 3.0 & 4.0 & 3.0 & 140 \\
$10 \%$ & 77.4 & 3.5 & 4.0 & 2.5 & 150 \\
$15 \%$ & 76.9 & 4.0 & 4.5 & 2.0 & 170 \\
\hline
\end{tabular}


Table (5): Extensogrph parameters of sprouted wheat and barley flour blends.

\begin{tabular}{ccccc}
\hline Treatments & $\begin{array}{c}\text { Elasticity } \\
(\text { B.U })\end{array}$ & $\begin{array}{c}\text { Extensibility } \\
(\mathbf{m m})\end{array}$ & $\begin{array}{c}\text { Proportional } \\
\text { number }\end{array}$ & $\begin{array}{c}\text { Energy } \\
\left(\mathbf{c m}^{2}\right)\end{array}$ \\
\hline Wheat flour(control) & 320 & 65 & 4.92 & 31 \\
Sprouted wheat flour & & & & \\
$5 \%$ & 270 & 70 & 3.85 & 36 \\
$10 \%$ & 260 & 75 & 3.46 & 33 \\
$15 \%$ & 250 & 85 & 2.94 & 28 \\
Sprouted barley flour & & & & \\
$5 \%$ & 180 & 80 & 2.25 & 25 \\
$10 \%$ & 150 & 80 & 1.88 & 20 \\
$15 \%$ & 110 & 85 & 1.29 & 14 \\
\hline
\end{tabular}

Izydorczyk et al. (2001) found that addition of either $\beta$-glucans or arabinoxylans of whole barley and barley components caused significant increases in peak dough resistance, mixing stability, and work input by using Mixograph and dynamic rheological measurements in all flour samples .

The proportional number (ratio between dough elasticity and dough extensibility) was decreased as replacement levels of sprouted wheat and barley increased. These findings indicated that the dough becoming softer and weaker than the control dough.

Energy values decreased gradually by increasing the replacement levels of both sprouted wheat and barley flour.

\subsection{Falling Number}

The results presented in Table (6) showed that the falling number values decreased for sprouted wheat and barley flour compared to the germinated ones.

The falling number had reverse relation with the percentage of added sprouted wheat flour, and sprouted barley flour. This shows that amylolytic enzymes activity increases as a function of added sprouted wheat flour and sprouted barley flour at different levels. On the other hand, the highest falling number was found in wheat flour, meaning that the amylase activity was inactive. On the contrary, the decrease in falling number for flour samples could be referred to activation of amylase during sprouting.
The liquefaction number was increased by increasing the addition of both sprouted wheat and barley flour levels. This means that increasing the addition percentage led to increase the amylolytic activity of the dough and consequently decreased the maximum viscosity. These results are agreement with those obtained by Dawidziak, (2014).

\subsection{Physical properties of cake}

The data in Table (7) demonstrated that the replacement of wheat flour with different levels of sprouted barley flour led to a highly increase in volume of produced cake compared with the control. The highest volume was found in cake with replacement level 5\% of sprouted barley flour $\left(544 \mathrm{~cm}^{3}\right)$ followed by $10 \%\left(465 \mathrm{~cm}^{3}\right)$, while the least one was found in the cake with $15 \%$ sprouted barley flour $\left(455 \mathrm{~cm}^{3}\right)$. It is worth mentioning that replacement by sprouted wheat flour resulted in volume relatively similar or slightly lower compared to the control. This may be due to the fact that cake does not rely on gluten for their structure (Gomez et al., 2008). The same trend of increase was found for weight cake produced with different levels of sprouted barley flour or sprouted wheat flour compared with control.

The cake made from different replacement levels of sprouted barley flour showed an increase in specific volume comparing with control cake made from $100 \%$ wheat flour. 
Table (6): Falling number and Liquefaction number of sprouted wheat and barley flour blends.

\begin{tabular}{lcc}
\hline \multicolumn{1}{c}{ Treatments } & Falling Number, Sec. & Liquefaction No. \\
\hline Wheat flour & 326 & 21.73 \\
Sprouted wheat flour & 62 & 500 \\
Barley flour & 180 & 46.15 \\
Sprouted barley flour & 62 & 500 \\
SW supplementation levels & & \\
\multicolumn{5}{c}{$5 \%$} & 196 & 41.09 \\
$10 \%$ & 185 & 44.44 \\
$15 \%$ & 148 & 61.22 \\
SB supplementation levels & & 193.54 \\
$5 \%$ & 61 & 375 \\
$10 \%$ & 66 & 500 \\
$15 \%$ & 62 & \\
\hline SW= sprouted wheat flour & SB= sprouted barley flour
\end{tabular}

Table (7): Physical characteristics of the cake replaced with different levels of sprouted wheat and sprouted barley flour.

\begin{tabular}{|c|c|c|c|}
\hline Cake samples & $\begin{array}{c}\text { Volume } \\
\left(\mathrm{cm}^{3}\right)\end{array}$ & $\begin{array}{l}\text { Weight } \\
\text { (g) }\end{array}$ & $\begin{array}{l}\text { Specific volume } \\
\left(\mathrm{cm}^{3} / \mathrm{g}\right)\end{array}$ \\
\hline Wheat flour(control) & $410^{d^{*}}$ & $199.17^{\mathrm{g}}$ & $2.06^{\mathrm{cd}}$ \\
\hline \multicolumn{4}{|c|}{ SW supplementation level } \\
\hline $5 \%$ & $410^{d}$ & $200.23^{\mathrm{f}}$ & $2.05^{d}$ \\
\hline $10 \%$ & $395^{\mathrm{e}}$ & $212.87^{d}$ & $1.86^{\mathrm{e}}$ \\
\hline $15 \%$ & $380^{f}$ & $208.69^{e}$ & $1.82^{\mathrm{e}}$ \\
\hline \multicolumn{4}{|c|}{ SB supplementation level } \\
\hline $5 \%$ & $544^{\mathrm{a}}$ & $217.23^{c}$ & $2.50^{\mathrm{a}}$ \\
\hline $10 \%$ & $465^{b}$ & $218.60^{b}$ & $2.13^{b}$ \\
\hline $15 \%$ & $455^{c}$ & $219.70^{\mathrm{a}}$ & $2.07^{\mathrm{c}}$ \\
\hline
\end{tabular}

SW= sprouted wheat flour

$\mathrm{SB}=$ sprouted barley flour

* Means with the same letter or letters are not significantly different at 0.05 level of significance 


\subsection{Texture profile analysis of cake}

The texture profile analysis for the cake supplemented with different levels of sprouted wheat and sprouted barley flour are presented in Table (8). Firmness, cohesiveness, gumminess, chewiness, springiness and resilience values of the cake produced with 5, 10 and $15 \%$ sprouted wheat flour were lower than cake control. All of parameters were decreased gradually by increasing the replacement levels of sprouted wheat flour. The same levels led to increase the cake volume, and softened the texture. The data are in agreement with Chaiya and Pongsawatmanit. (2011).

Cake produced with a replacement level of 5\% sprouted barley flour was higher in all parameters compared with the control cake. Meanwhile, decreased gradually by increasing flour replacement levels except gumminess and resilience. The decrease in texture may be due to the decrease in sponginess (springiness) of cakes resulting from the decrease in gluten content (Desai et al., 2010). content. Water activity had effects on aroma, flavor, color, stability, texture and acceptability of raw and processed food products (Rockland,1969).

Water activity $\left(\mathrm{a}_{\mathrm{w}}\right)$ of cake supplemented with different levels of sprouted wheat flour and sprouted barley flour were presented in Table (9). It could be noticed that water activity slightly increased by increasing sprouted wheat and barley flour levels. Concerning the effect of storage time on water activity, it could be concluded that water activity decreased gradually in all tested samples by increasing the storage period.

Similar results were obtained by Arshad et al. (2014) who prepared cookies from wheat flour, barley and oat.

\subsection{Sensory evaluation of cake}

Sensory evaluation of cake supplemented with different levels of sprouted wheat flour and sprouted barley flour are presented in Table (10). The data showed that there is no significant difference in crust and crumb color between cake control and cake prepared with sprouted wheat

Table (8): Texture profile analysis of the cake replaced with different levels of sprouted wheat and sprouted barley flour.

\begin{tabular}{ccccccc}
\hline \multicolumn{1}{c}{ Cake samples } & $\begin{array}{c}\text { Firmness } \\
(\mathrm{N})\end{array}$ & Cohesiveness & $\begin{array}{c}\text { Gumminess } \\
(\mathrm{N})\end{array}$ & $\begin{array}{c}\text { Chewiness } \\
(\mathrm{Nm})\end{array}$ & $\begin{array}{c}\text { Springiness } \\
(\mathbf{m m})\end{array}$ & Resilience \\
\hline $\begin{array}{l}\text { Wheat flour } \\
\text { (control) }\end{array}$ & 3.580 & 0.595 & 2.128 & 1.519 & 0.714 & 0.336 \\
SW supplementation level & & & & & \\
$5 \%$ & 3.530 & 0.560 & 1.977 & 1.343 & 0.679 & 0.327 \\
$10 \%$ & 2.750 & 0.511 & 1.328 & 0.894 & 0.673 & 0.302 \\
$15 \%$ & 2.600 & 0.363 & 0.997 & 0.496 & 0.497 & 0.233 \\
SB supplementation level & & & & & \\
$5 \%$ & 5.790 & 0.673 & 2.768 & 2.919 & 0.797 & 0.392 \\
$10 \%$ & 5.440 & 0.648 & 3.335 & 2.203 & 0.699 & 0.438 \\
$15 \%$ & 4.270 & 0.576 & 3.660 & 1.934 & 0.660 & 0.415 \\
\hline
\end{tabular}

SW= sprouted wheat flour

$\mathrm{SB}=$ sprouted barley flour

\subsection{Water activity of cake}

The water activity has been related to chemical, biological and physical properties of foods and other products as compared to its total moisture flour at 5,10 and $15 \%$ replacement levels. Whereas, there were significant differences in shape, graining of crumb, texture, taste and odor in the same cake samples levels. 
Table (9): Water activity of the cake replaced with different levels of sprouted wheat and sprouted barley flour at different storage period.

\begin{tabular}{cccc}
\hline \multirow{2}{*}{ Tested samples } & \multicolumn{3}{c}{ Storage period(day) } \\
\cline { 2 - 4 } Wheat flour(control) & Zero time & 3 days & d days \\
SW supplementation level & 0.919 & 0.889 & 0.898 \\
$5 \%$ & & & \\
$10 \%$ & 0.886 & 0.881 & 0.877 \\
$15 \%$ & 0.888 & 0.875 & 0.870 \\
SB supplementation level & 0.901 & 0.894 & 0.894 \\
$5 \%$ & & & \\
$10 \%$ & 0.914 & 0.894 & 0.881 \\
$15 \%$ & 0.928 & 0.910 & 0.910 \\
Means & 0.929 & 0.923 & 0.898 \\
\hline
\end{tabular}

SW= sprouted wheat flour $\quad \mathrm{SB}=$ sprouted barley flour

Table (10): Sensory evaluation of the cakes supplemented with different levels of sprouted wheat and barley flour.

\begin{tabular}{lcccccccccc}
\hline $\begin{array}{l}\text { Cake } \\
\text { treatment }\end{array}$ & $\begin{array}{c}\text { Shape } \\
(10)\end{array}$ & $\begin{array}{c}\text { Volume } \\
(15)\end{array}$ & $\begin{array}{c}\text { Crust } \\
\text { characteristics } \\
(5)\end{array}$ & $\begin{array}{c}\text { Graining } \\
\text { of } \\
\text { crumb(10) }\end{array}$ & $\begin{array}{c}\text { Texture } \\
(15)\end{array}$ & $\begin{array}{c}\text { Crumb } \\
\text { color(5) }\end{array}$ & $\begin{array}{c}\text { Taste } \\
(\mathbf{3 0})\end{array}$ & $\begin{array}{c}\text { Odor } \\
(10)\end{array}$ & $\begin{array}{c}\text { Total } \\
(\mathbf{1 0 0})\end{array}$ & Acceptance \\
\hline $\begin{array}{l}\text { Wheat } \\
\text { flour } \\
\text { (control) }\end{array}$ & $\mathbf{8 . 6}^{\mathrm{a}^{*}}$ & $\mathbf{1 3 . 6}^{\mathrm{b}}$ & $\mathbf{4 . 1}^{\mathrm{a}}$ & $\mathbf{8 . 9}^{\mathrm{a}}$ & $\mathbf{1 3 . 6}^{\mathrm{a}}$ & $4.2^{\mathrm{a}}$ & $26.7^{\mathrm{c}}$ & $\mathbf{8 . 8 ^ { \mathrm { a } }}$ & $\mathbf{8 8 . 5}$ & good \\
& & & & & & & & & &
\end{tabular}

SW supplementation level

$\begin{array}{ccccccccccr}5 \% & 8.2^{\mathrm{b}} & 13.2^{\mathrm{c}} & 4.1^{\mathrm{a}} & 8.3^{\mathrm{b}} & 13.2^{\mathrm{b}} & 4.1^{\mathrm{a}} & 27.3^{\mathrm{a}} & 8.6^{\mathrm{b}} & 87.0 & \operatorname{good} \\ 10 \% & 8.2^{\mathrm{b}} & 13.0^{\mathrm{cd}} & 4.0^{\mathrm{a}} & 8.3^{\mathrm{b}} & 13.2^{\mathrm{b}} & 4.1^{\mathrm{a}} & 27.0^{\mathrm{b}} & 8.5^{\mathrm{c}} & 86.7 & \operatorname{good} \\ 15 \% & 7.9^{\mathrm{c}} & 12.9^{\mathrm{d}} & 4.0^{\mathrm{a}} & 8.3^{\mathrm{b}} & 13.2^{\mathrm{b}} & 4.2^{\mathrm{a}} & 26.9^{\mathrm{b}} & 8.6^{\mathrm{b}} & 85.9 & \operatorname{good}\end{array}$

SB supplementation level

\begin{tabular}{|c|c|c|c|c|c|c|c|c|c|c|}
\hline $5 \%$ & $8.6^{\mathrm{a}}$ & $13.8^{\mathrm{a}}$ & $4.1^{\mathrm{a}}$ & $8.1^{c}$ & $12.8^{\mathrm{c}}$ & $3.5^{\mathrm{b}}$ & $26.6^{\mathrm{cd}}$ & $8.4^{c}$ & 86.8 & good \\
\hline $10 \%$ & $8.5^{\mathrm{a}}$ & $13.8^{\mathrm{a}}$ & $4.1^{\mathrm{a}}$ & $8.0^{c}$ & $12.6^{\mathrm{d}}$ & $3.6^{\mathrm{b}}$ & $26.6^{\mathrm{cd}}$ & $8.4^{\mathrm{c}}$ & 85.5 & good \\
\hline $15 \%$ & $7.9^{c}$ & $13.9^{\mathrm{a}}$ & $3.9^{a}$ & $7.3^{\mathrm{d}}$ & $12.0^{\mathrm{e}}$ & $3.6^{\mathrm{b}}$ & $26.5^{d}$ & $8.4^{\mathrm{c}}$ & 82.9 & good \\
\hline
\end{tabular}


On the other side, the highly significant difference the found in graining of crumb, texture, crumb color, taste and odor between control cake and cake prepared with sprouted barley flour. But, there was no significant difference in shape, volume and crust characteristics of cake prepared with different levels of sprouted barley flour compared with the control. These results may be due to the high fiber content in the cake samples with barley replacement levels which affect the cake properties as color (Hussein et al., 2013) .The lower value of texture may be due to the decrease in sponginess of the cakes resulting from the decrease in gluten content (Desai et al., 2010).

The results of control cake treatment ranked at the top due to excellent in most parameters, followed by the cake with $5 \%$ sprouted wheat flour or sprouted barley flour then $10 \%$ sprouted wheat flour. The cake samples prepared from wheat flour supplemented by sprouted wheat or sprouted barley flour had a good overall acceptability.

\section{REFERENCES}

A.A.C.C. (1983). American Association of Cereal Chemists. Published by American Association of Cereal Chemists. $8^{\text {th }}$ Ed. Method 10-56, The Association. St. paul, Minnesota, U.S.A.

A.A.C.C. (2000). American Association of Cereal Chemists. Published by American Association of Cereal Chemists, $10^{\text {th }} \mathrm{Ed}$ International St. paul, Minnesota, U.S.A.

A.A.C.C. (2010). American Association of Cereal Chemists. Approved Methods of the American Association of Cereal Chemists, $11^{\text {th }}$ International St. Paul, Minnesota, U.S.A.

A.O.A.C.(2005). Association of Official Analytical Chemists. Official Methods of Analysis of Association of Official Analytical Chemists International, $18^{\text {th }}$ Ed., Maryland, DC. U.S.A.

Alemu M. K. (2009). The Effect of Natural Fermentation on Some Anti nutritional Factors, Minerals, Proximate Composition and Sensory Characteristics in Sorghum Based Weaning Food. M.Sc. Thesis, Addis Ababa Univ., Ethiopia, 83 p.

Arshad U., Anjum F., Muhammad A., Rehman U.R., Salim M. and Sohaib M. (2014).
Development and characterization of multigrain cookies. Pakistan J. of Food Scie., 24(1): 1- 5.

Badi W. H. I. (2004). Effect of Processing on Anti -Nutritional Factors and Minerals Bioavailability of Sorghum, Ph. D. thesis. Department of Food Scie. and Techn. Fac. of Agric., Univ. Khartoum, Sudan.

Bennion E. B. and Bamford G.S.T.(1973). The technology of cake making process, $6^{\text {th }} \mathrm{Ed}$., Published by Blacking Academic and Professional Chapman and Hall, London, PP. 112-120, 277 and 185-288.

Bhavsar K., Shah P., Kumar Soni S. and Khire J. M. (2008). Influence of pretreatment of agriculture residues on phytase production by Aspergillusniger. Afri. J. Biotech., 7 (8): 1101-1106.

Bindra G.S., Gibson R.S. and Thompson L.U. (1986). [Phytate][calcium]/[zinc] ratios in Asian immigrant lacto-ovo vergetarian diets and their relationship to zinc nutriture. Nutr. Res., 6:475-483.

Borode V. P., Kadam S. S. and Salunfhe D. K. (1984). Changes in phytate phosphorus and minerals during germination and cooking of horse gram and moth bean. Plant Food for Human Nutrition, 34(2): 151-157.

Bourne M.C. (2003). Food texture and viscosity: concept and measurement. $2^{\text {nd }}$ Ed. pp. 257290, Academic Press, London, U.K.

Chaiya B. and Pongsawatmanit R. (2011). Quality of batter and sponge cake prepared from wheat- tapioca flour blends. Kasetsart J. Natl. Scie., 45: 305-313.

Davies N.T., Carswell A.J.P. and Mills C.F. (1985). The effect of variation in dietary calcium intake on the phytate-zinc interaction in rats. In: Trace Elements in Man and Animals TEMA-5. Mills CF, Bremmer I and Chesters JK (eds), pp. 456457. CAB: Wallingford, UK.

Dawidziak M.Z. (2014). Sprouted wheat grain with ferreting over expression as a potential source of iron for cereal product fortification. Eur. Food Res. and Tech., 238: 829- 835.

Desai A.D., Kulkarni, S.S., Sahoo A. K., Ranveer, R. C. and Dandge P. B. (2010). Effect of supplementation of malted ragi flour on the nutritional and sensorial quality 
characteristics of cake. Jo. of Food Scie., 2 (1): $67-71$.

Dhingra S. and Jood S. (2001). Organoleptic and nutritional evaluation of wheat breads supplemented with soybean and barley flour. Food Chem., 77: 479-488.

Duncan, D.B. (1995). Multiple range and multiple F tests. Biometrics, 11: 142.

Eissa H .A., Hussein A.S. and Mostafa B.E. (2007). Rheological Properties and Quality Evaluation of Egyptian Balady Bread and biscuits Supplemented With Flours of Un germinated and Germinated Legume Seeds or Mushroom. Polish J. of Food and Nutr. Scie., 57: ( 4) 487-496.

Finney P.L. (2001). Effects of falling-number sample weight on prediction of $\alpha$-amylase activity. Cereal Chem., 78 (4): 485-487.

Gomez M., Oliete B., Rosell C.M., Pando V. and Fern-ndez E. (2008). Studies on cake quality made of wheat - chickpea flour blends. LWT-Food Scie. and Tech., 41: 1701-1709.

Hallberg L., Brune M. and Rossander L. (1989). Iron absorption in man: ascorbic acid and dose-dependent inhibition by phytate. American J. of Clinical Nutr., 49:140-144.

Hallén E. B and Ainsworth P. (2004). Effect of fermented/ germinated cowpea flour addition on the rheological and baking properties of wheat flour. J. of Food Engin. 63(2): $177-184$.

Harland B. F. and Oberleas D. (1977). A modified method for phytate analysis using an ion-exchange procedure: application to textured vegetable proteins. Cereal Chem., 54: 827-832.

Holas J. and Tipples K.H. (1978). Factors affecting farinograph and baking absorption. I. Quality characteristics of flour streams. Cereal Chem., 55: 637-652.

Hussein A.M.S., Kamil M.M., Hegazy N.A. and Abo-El-Nor S.A.H. (2013). Effect of wheat flour supplemented with barley and /or corn flour on balady bread quality. Polish Journal Food and Nutr. Scie., 63(1) : 11-18.

Indrani D. and Roa G.V. (2000). Effect of chemical composition on wheat flour and functional properties of dough on the quality of south Indian parotta. Food Research International, 33: 875-881.
Izydorczyk M.S, Hussain A. and MacGregor A.W. (2001). Effect of barley and barley components on rheological properties of wheat dough. J. of Cereal Scie., 34 (3): 251260.

Kayodé A. P. P. (2006). Diversity, Users' Perception and Food Processing of Sorghum: Implications for Dietary Iron and Zinc Supply. Ph.D. Thesis, Wageningen Univ., Wageningen, Netherlands, $151 \mathrm{p}$.

Khattak AB., Zeb A., Bibi N., Khalil S.A. and Khattak M.S. (2007). Influence of germination techniques on phytic acid and polyphenols content of chickpea (Cicer arietinum L.) sprouts. Food Chemistry, 104:1074-1079.

Konietzny U. and Greiner R. (2002). Molecular and catalytic properties of phytatedegrading enzymes (phytases). International J. of Food Scie. and Tech., 37, 791-812.

Miś A.(2003). Changes in water absorption of gluten as a result of sprouting of wheat grain. Int. Agroph., 17, 25-30.

Mohamed A., Perera P.A. and Hafez Y. (1986). New chromophore for phytic acid determination. Cereal Chem., 63(6): 475478.

Morris ER. and Ellis R. (1985). Bioavailability of dietary calcium-effect of phytate on adult men consuming non-vegetarian diets. In: ACS Symposium Series 75: Nutritional Bioavailability of Calcium. Kies C (eds), p. 63. American Chem. Soci.: Washington, DC, USA.

Morris E. R. and Ellis R. (1989). Usefulness of the dietary phytic acid/zinc molar ratio as an index of zinc bioavailability to rats and humans. Biological Trace Element Res., 19: 107-117.

Muahamed N., Faqir M.A., Rai M.A., Moazzam R.K., Shahzad H. and Muhammad S.J. (2010). An overview of anti-nutritional factors in cereal grains with special reference to wheat- A review. Pakistan J. of Food Scie., 20 (1- 4): 54 - 61.

Nadife J. and Abbo E. (2009). Functional foods: prospects and challenges in Nigeria. J. Sci. Tech.,1 (5): 1-6.

Piga A. Catzeddu P., Farris S., Roggio T. , Sanguinetti A. and Scano E. (2005). Texture evaluation of Amaretti cookies 
during storage. Eur. Food Res. and Tech. 221: 387-391.

Rockland L. B. (1969). The practical approach to better low moisture foods: Water activity and storage stability. Food Tech., 23: 12411247.

Sandberg A S., Anderson H., Carlesson N.G. and Sandstrom B. (1987). Degradation products of bran phytate formed during digestion in the human small intestine: effects of extrusion cooking on digestibility. J. Nut. 117: 2061-2065.

Sangronis E. and Machado C.J.(2007). Influence of germination on the nutritional quality of Phaseolus vulgaris and Cajanus cajam. LWT - Food Sci. and Tech., 40: 116-120.

Shimi G. and Hasnah H. (2013). Does cooking affect the phytate content in local soy based dishes? Int. Food Res. J., 20 (5): 2873-2880.

SPSS (1997). Analysis without anguish. S.J. Coakes and L.G. Steed (ed), Wiley,
Singapore. pp. 276. ISBN 0 - $471-33869$ 9.

Tizazu S., Urga K., Belay A., Abuye, C. and Retta, N. (2011). Effect of germination on mineral bioavailability of sorghum based complementary foods. Afri. J. Food, Agric., Nutr. and Devel., 11(5): 5083-5095.

Turnlund J.R., King J.C., Keyes W.R., Gong B. and Michel M.C. (1984). A stable isotope study of zinc absorption in young men: effects of phytate and $\alpha$-cellulose. Amer. J. Clinical Nutr., 40: 1071-1077.

Uwaegbute A.C., Iroegbu C.U. and Eke O. (2000). Chemical and sensory evaluation of germinated cowpeas (Vigna unguiculata) and their products. Food Chem., 68: 141146.

Youssef H. (2008). Nutritional assessment of talbina and talbina fortified biscuits. Home Econ., 18: 3-14.

\section{تأثير استبدال دقيق القمح والشعير المستنبت على جودة الكيك \\ منال حجاج عبد القادر - ناهد سامى يوسف * ـ سماء محمود السيد* - جليلة على حامد عسكر*

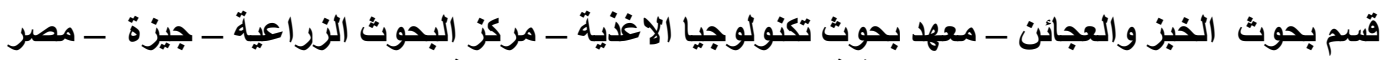

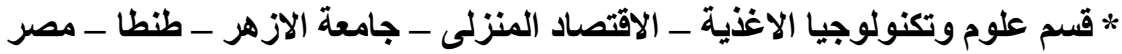

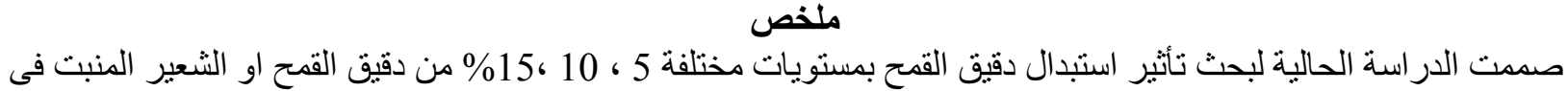

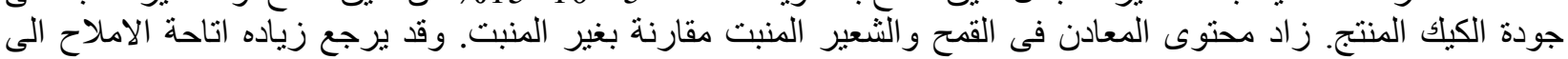

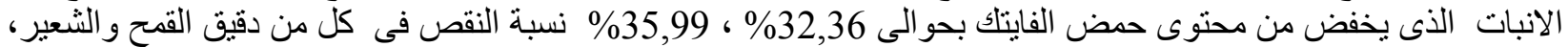
على التو اللى ـ تناقصت النسبة المئوية للفايتات / الفوسفور الكلى فى كل من دقيق القمح و الثعير المنبت التى

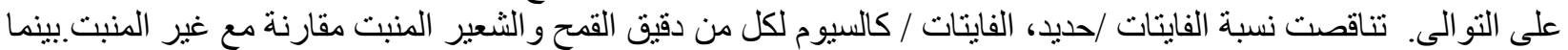

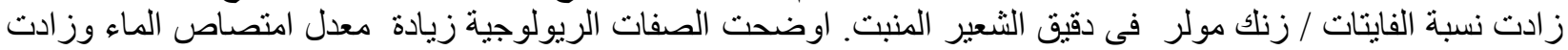

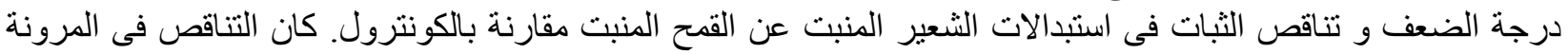

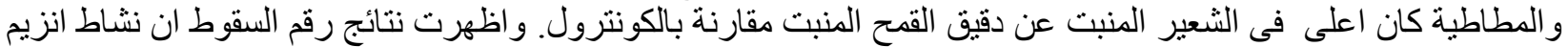

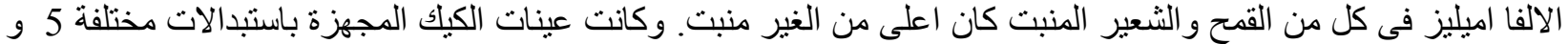

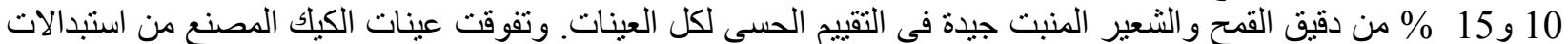

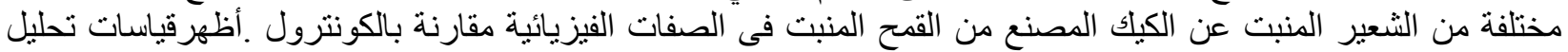

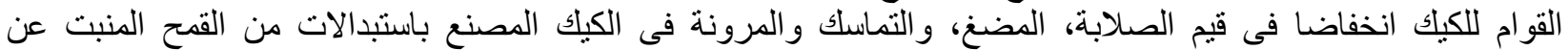

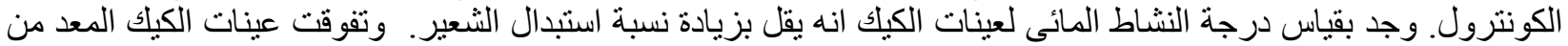
استبدالات مختلفة من دقيق القمح المنبت فى صفات التحبب و القو ام ولون اللبابة، الطعم، الر ائحة عن دقيق الشعير المنبت. 